\section{A (in)constitucionalidade da Súmula 385 do Superior Tribunal de Justiça}

\section{The (Um) constitutionality of Precedent 385 of the Superior Court of Justice}

\author{
Valmir Cesar Pozzetti * \\ Aline Susana Canto Pantoja **
}

Resumo: O presente artigo busca analisar, à luz do fundamento da dignidade da pessoa humana e dos direitos e garantias fundamentais consagrados pela Constituição Federal de 1988, a constitucionalidade da Súmula 385, editada do Superior Tribunal de Justiça (STJ). Este enunciado veda ao consumidor que possua pelo menos um registro legítimo em órgão de proteção crédito exigir judicialmente indenização por dano moral em face de posterior anotação, ainda esta última seja irregular. O método de abordagem utilizado nesta pesquisa é o dedutivo, de procedimento cientifico, com utilização de técnicas de pesquisas bibliográfica e jurisprudencial.

Palavras-chave: Precedente judicial; súmula persuasiva; súmula 385 do STJ; constitucionalidade.

Abstract: This article seeks to examine, in the light of the foundation of human dignity and the fundamental rights and guarantees enshrined in the Constitution of 1988, the constitutionality of Precedent 385, edited from the Superior Court of Justice (STJ). This statement prohibits the consumer that has at least one legitimate record in a credit protection agency of judicially demanding compensation for moral damage in the face of subsequent annotation, although the latter is irregular. The method of approach used in this study was deductive, scientific procedure, with the use of techniques of bibliographic research and case.

Keywords: Previous judicial; precedent persuasive; precedent from the Supreme Court 385; constitutionality.
* Doutor em Biodireito/Direito Ambiental - Direito Comparado pela Universitè de Limoges/França (título revalidado pela Univ. Federal de Pernambuco). E-mail: pozzetti@uea.edu.br

** Bacharelanda em Direito pela Faculdade Martha Falcão. E - $m$ a $\quad \mathrm{i}$ 1 aline.pantoja@uol.com.br 


\section{INTRODUÇÃO}

Sob o argumento de conferir maior segurança e coerência às relações jurídicas, o Supremo Tribunal Federal e o Superior Tribunal de Justiça têm adotado cada vez mais a prática de editar súmulas. Estas, em linhas gerais, condensam o entendimento dessas Cortes a respeito de temas que são recorrentes entre seus julgados, deixando claro o sentido de determinados comandos legais que, em tese, poderiam gerar multiplicidade de interpretações e consequências jurídicas.

Com este intuito foi editada pela Segunda Seção do Superior Tribunal de Justiça a Súmula 385, resultado do julgamento do recurso especial representativo 1.062.336/RS, de relatoria da Ministra Nancy Andrighi. A Súmula em questão estabelece que: "Da anotação irregular em cadastro de proteção crédito, não cabe indenização por dano moral, quando preexistente legítima inscrição, ressalvado o direito ao cancelamento".

O entendimento do STJ é no sentido de que um consumidor que já possua pelo menos um registro legítimo em órgão de proteção crédito, não experimenta qualquer constrangimento ou prejuízo em caso de posterior anotação irregular, não podendo consequentemente exigir judicialmente reparação relativa a tal anotação.

Por essa interpretação, a referida súmula tem sido objeto de críticas por parte de doutrinadores e operadores do direito que entendem que a mesma contrariadiversos princípios e direitos assegurados na Constituição Federal de 1988, como o direito de ação, previsto no art. $5^{\circ}$, inciso XXXV, direitos inerentes à personalidade, como a honra, constante também no art. $5^{\circ}$, inciso $\mathrm{X}$; e, por via de consequência, o princípio da dignidade da pessoa humana.

Não obstante, há doutrinadores que defendem a aplicabilidade desta e de outras súmulas pelos Tribunais Superiores, sob o argumento principal de que estas, além possibilitarem economia e celeridade processual, desafogando o Judiciário de demandas repetidas, garantem a unidade da ordem jurídica, assim como a segurança jurídica e a igualdade entre os jurisdicionados.

Diante da controvérsia doutrinária, o presente artigo pretende analisar a Súmula 385 do STJ sob a ótica dos direitos e garantias fundamentais consagrados pela Constituição Federal de 1988 e, sobretudo, em face do princípio da dignidade da pessoa humana, enquanto fundamento do ordenamento jurídico brasileiro. Busca-se, ao final, uma conclusão quanto à possível constitucionalidade ou, ao revés, a inconstitucionalidade da referida súmula. 
Para tanto, pretende-se, inicialmente, contextualizar a origem do precedente judicial no ordenamento jurídico brasileiro. Nesse sentido, será desenvolvido um breve relato sobre a introdução dos precedentes, que data do período colonial. Também serão abordados os aspectos controvertidos a respeito do tema junto à doutrina mais autorizada, seguida de uma abordagem conceitual a respeito do instituto súmula, estabelecendo uma diferenciação entre súmula vinculante e súmula não vinculante ou persuasiva.

No tópico subsequente, será analisada a introdução propriamente dita da Súmula 385 do STJ. Será preliminarmente abordada, ainda que brevemente, a questão da responsabilidade civil pela inserção do nome deconsumidor nos bancos de dados de devedores inadimplentes à luz das normas contidas no Código de Defesa do Consumidor. Nesse ponto, serão relacionadas algumas das jurisprudências do STJ a respeito do tema, para ao final, discorrer precisamente sobre a Súmula 385 do STJ e sobre os precedentes jurisprudenciais que possibilitaram a sua edição.

Com base no método indutivo de abordagem, no último tópico será enfrentada a questão da constitucionalidade da Súmula 385 do STJ. Para tanto, o princípio da dignidade da pessoa humana será analisado como fundamento da ordem jurídico-constitucional brasileira, bem como sua relação com os direitos e garantias fundamentais. Por fim, serão relacionados os direitos fundamentais diretamente violados pela citada Súmula e as conseqüências jurídicas de sua adoção indiscriminada.

\section{PRECEDENTES JUDICIAIS NO ORDENAMENTO JURÍDICO BRASILEIRO}

O precedente judicial pode ser entendido como uma norma jurídica elaborada pelo magistrado diante de um caso concreto. Trata-se da possibilidade/ obrigatoriedade de determinada decisão judicial influenciar casos futuros similares. Didier Júnior, Braga e Oliveira (2010, p.385), conceituam o precedente como "decisão judicial tomada à luz de um caso concreto, cujo núcleo essencial pode servir como diretriz para o julgamento posterior de casos análogos".

\subsection{Introdução do precedente judicial no Brasil}

Apesar do instituto do precedente ter adquirido notória importância no sistema jurídico brasileiro apenas nos últimos anos, em razão de emendas 
constitucionais e reformas processuais, sua aplicação pode ser identificada em diversos momentos históricos, com os primeiros registros ainda do período colonial, por influência do direito português.

Nesse sentido, de acordo com Ribas (2012, p.40) são reconhecidos como os primeiros esforços no sentido de uniformizar a jurisprudência os assentos e os prejulgados. Os assentos podem ser definidos como entendimentos de observância obrigatória proferidos em julgamentos na Casa de Suplicação do Brasil. Foram adotados, no final do período colonial, por meio das Ordenações Manuelinas.

Por outro lado, os prejulgados, inseridos no ordenamento jurídico no período republicano, através da Lei Federal n. ${ }^{\circ} 319$, de 25 de novembro de 1936, seriam pronunciamentos prévios dos tribunais que deveriam ser seguidos em caso de divergência na intepretação da mesma lei.

Apesar da aplicação desses e de outros institutos no sistema jurídico brasileiro ao longo da história, a primeira proposta formal de adoção de súmulas no ordenamento jurídico brasileiro foi apresentada somente na década de sessenta do século passado, pelo então Ministro do Supremo Tribunal Federal, Victor Nunes Leal. Naquela a ocasião, Leal indicou a necessidade do STF editar pequenos enunciados que pudessem traduzir o entendimento predominante dessa Corte a respeito de matérias que, por sua complexidade, geram divergência nos tribunais.

Além disso, segundo Shafer (2012, p.21), o Ministro teria justificado a necessidade de edição de súmulas, pois estas teriam a função "de orientação e de informação, porquanto sempre foi difícil para o cidadão tomar conhecimento da jurisprudência $[\ldots]$ ".

Com tais objetivos, a proposta de adoção das sumulas foi aprovada e inserida no ordenamento jurídico por meio de uma Emenda no Regimento Interno do STF. Estes enunciados ficaram conhecidos como "Súmulas da jurisprudência dominante do Supremo Tribunal Federal".

Com o passar dos anos, a adoção súmulas e de outros de institutos dessa natureza foram se tornando cada vez mais frequentes em nosso ordenamento, gerando intensos debates doutrinários, especialmente por não ser o precedente judicial, para alguns doutrinadores, um instituto típico do sistema judicial pátrio.

Em verdade, o precedente judicial ganhou relevo em países em que se desenvolveu o sistema denominado Common Law, como é o caso dos Estados Unidos e Inglaterra. Neste sistema, as decisões emanadas por uma Corte 
Superior possuem eficácia vinculante em relação aos demais juízos hierarquicamente inferiores.

Por outro lado, nos países em que se desenvolveu o sistema Civil Law, como é o caso do Brasil, a fonte principal do direito é a legislação. O precedente judicial se apresentaria como fonte secundária, não possuindo a decisão judicial força obrigatória em relação a futuras decisões.

Parece residir neste aspecto o cerne da divergência: embora presente em qualquer sistema jurídico, inclusive no Brasil, conforme apontado anteriormente, o instituto do precedente judicial nãoé um instituto característico do sistema jurídico pátrio. Aplicado ostensivamente no âmbito de uma família jurídica que essencialmente privilegia as decisões jurisdicionais, os precedentes estabelecidos pelos tribunais superiores tornam-se regra perante casos futuros e idênticos levados à apreciação do judiciário.

Para Marins (2012, p.6):

Esta questão da força vinculante do precedente é o elemento que diferencia com mais clareza o papel da jurisprudência no sistema da common law, em comparação ao sistema da civil law. Enquanto neste último a solução do caso posto a julgamento passa pela aplicação da disposição legal incidente ao caso concreto, no sistema commomlaw a solução do caso em julgamento deverá ser encontrada, salvo exceções, no precedente judicial que julgou caso análogo em momento anterior.

Diante da divergência quanto à adoção dos precedentes judiciais, torna-se indispensável para compreensão do tema, realizar um breve estudo a respeito das correntes doutrinárias favoráveis e desfavoráveis à aplicação desses institutos.

\subsection{Aspectos polêmicos quanto à adoção de precedentes no Brasil}

Nos últimos anos, várias reformas no ordenamento jurídico brasileiro possibilitaram a introdução de institutos jurídicos de valorização dos precedentes judiciais como fonte de direito. Parte da doutrina entende que tais reformas visam dar resposta ao que se convencionou chamar de "crise" do Judiciário, caracterizada, segundo doutrina majoritária, pela morosidade dos processos judiciais; pelo aumento gradativo da demanda judicial e pela imprevisibilidade dessas decisões, que tornam este Poder cada vez mais desacreditado perante a sociedade. 
Esta última característica é, para Marins (2012, p.12), o argumento mais forte para adoção sistemática de institutos ligados aos precedentes judiciais:

Notadamente se está a buscar, em longo prazo, por meio destas reformas, justamente a estabilização das decisões judiciais, a partir da valorização da jurisprudência como fonte criativa do Direito e da proposta de vinculação de precedentes do Supremo Tribunal Federal aos juízos de hierarquia inferior. $[\ldots$.

Não bastassem os inúmeros problemas que o país enfrenta nas searas socioeconômica e política, por exemplo, é inegável que a instabilidade do comportamento do Poder Judiciário é um dos elementos que vem a tumultuar o convívio social. Não se fala aqui apenas da questão da impunidade, que se tornou verdadeiro clichê, mas também da insegurança do jurisdicionado, que tem de conviver, por exemplo, com a incerteza do provimento jurisdicional, que ora dispõe em um sentido, ora em outro, diametralmente oposto.

Para outros doutrinadores, o respeito aos precedentes judiciais em nosso ordenamento é tão necessário que deveria torna-se obrigatório para toda e qualquer demanda levada ao Judiciário. Para Marinori (2011, p.482), por exemplo, muito mais que conferir celeridade ao Judiciário, a adoção dos precedentes judiciais têm como finalidades primordiais garantir a unidade e coerência da ordem jurídica, assim como a segurança e a igualdade.

Por esse motivo, o autor critica o fato de que os precedentes, em especial as súmulas, foram associados a mecanismos de resolução de casos fáceis, ficando em segundo plano os seus principais objetivos. No entendimento de Marinori (2011, p.483):

Se o precedente obrigatório pode permitir a racionalização do Poder Judiciário, essa é apenas uma consequência daquilo que realmente justifica a sua instituição. Não se quer dizer que fator desta espécie não tem importância, mas somente que é secundário, ou seja, que depende de o sistema ser pensado a partir da sua verdadeira substância. O verdadeiro problema é ignorar que o instituto da súmula pode servir para garantir a necessidade de coerência da ordem jurídica e de tutela da igualdade e da segurança.

Entretanto, há opiniões contrárias à introdução desses institutos no sistema jurídico brasileiro. Porto (2012, p.20), por ocasião da tramitação no Congresso Nacional da Proposta de Emenda n. ${ }^{\circ} 45 / 2004$, a qual introduziu no ordenamento jurídico brasileiro o instituto da súmula vinculante pelo Supremo Tribunal Federal, 
já advertia quanto às possíveis consequências da vinculação dos magistrados aos precedentes judiciais:

Contudo, se há, de um lado, o saudável desejo de prestigiamento das decisões judiciais dos tribunais superiores, aos efeitos de oferecer segurança jurídica ao cidadão que passa a desfrutar de um judiciário mais previsível, há também, de outro, a grave preocupação, nos termos em que está posto o projeto, de limitar a capacidade criativa do juízo sujeito à vinculação, circunstância, hoje, intolerável, eis que aquela se constitui também na concepção mais moderna do sistema romano-germânico brasileiro em legítima fonte de direito.

No mesmo sentido, RIBAS (2008, p.53) manifestou-se contrário precisamente à adoção de súmulas no ordenamento brasileiro, por entender que estas não são compatíveis com o sistema jurídico pátrio. Conforme Ribas (2008, p.54):

As súmulas não se compadecem com o nosso sistema escrito de direito positivo. Num ordenamento preponderantemente consuetudinário, natural que certas orientações jurisprudenciais se cristalizem em enunciados estáveis como são os cases do Direito americano. Mas as leis escritas já carecem de flexibilidade bastante, de modo que procurar ainda mais endurecer a sua interpretação, mediante proposições que civilmente possam ser afastadas, significa abrir mão do pouco que nos deixa o sistema para a modelação do Direito positivo às circunstancias de cada caso concreto.

Em que pese os posicionamentos acima expostos, especialmente aqueles contrários à adoção de precedentes no ordenamento jurídico brasileiro, e que expressam a controvérsia doutrinária a respeito do tema, é fato que os precedentes judiciais, e em particular as súmulas, ganham cada vez mais espaço em nosso sistema jurídico, alterando decisivamente a atuação dos magistrados diante do caso concreto, que passam a adotá-las não apenas como uma faculdade, mas como uma obrigatoriedade.

\subsection{As súmulas persuasivas do Superior Tribunal de Justiça}

Conforme exposto anteriormente, écada vez mais frequente a adoção de institutos voltados à valorização dos precedentes no ordenamento jurídico brasileiro, em especial pelas Cortes Superiores. De acordo com Marinori (2011, 
p.459), no Supremo Tribunal Federal, são exemplos de precedentes judiciais, as decisões proferidas em controle concentrado e difuso de constitucionalidade, a repercussão geral no recurso extraordinário e as súmulas vinculantes, anteriormente mencionadas.

No Superior Tribunal de Justiça, também de acordo com o supracitado autor, são exemplos de respeito aos precedentes o dever de uniformizar a interpretação da lei federal, as decisões com força obrigatória, o julgamento de recursos repetitivos e a admissão da reclamação para tutela da autoridade dos precedentes.

As súmulas, objeto de estudo do presente artigo, têm por objetivo principal deixar claro o sentido de determinados comandos legais que, em tese, poderiam gerar multiplicidade de interpretações e consequências jurídicas. Buscam sintetizar a interpretação de um órgão jurisdicional a respeito de determinada lei ou situação fática não abordada de forma clara pelo legislador. Para Soares (2008, p.96):

A palavra súmula, na seara jurídica, nada mais é que a padronização de decisões julgadas por um determinado tribunal, uma vez que as mesmas foram tomadas repetidas vezes. Dessa forma, a súmula, depois de publicada com numeração em repertório oficial do órgão, torna-se jurisprudência uniforme consuetudinária, podendo ser invocada para solução de demais casos que se enquadrem em sua ementa.

Nesse contexto, as súmulas podem ter, quanto aos seus efeitos, caráter vinculante ou persuasivo. No primeiro caso, enquadram-se somente as súmulas editadas pelo Supremo Tribunal Federal (STF), com esta nomenclatura, e com fundamento no art. 103-A e parágrafos da Constituição Federal de 1988. Tais enunciados, por conter comandos obrigatórios, são aplicáveis a todo o Judiciário e Administração Pública e possibilitam, em não havendo cumprimento, reclamação junto a Corte Suprema.

No segundo caso, estão inclusas todas as demais súmulas dostribunais, inclusive aquelas editadas pelo Superior Tribunal de Justiça. Nas palavras de Tucci (apud DIDIER JÚNIOR, BRAGA e OLIVEIRA, 2010, p.348), “o precedente persuasivo não tem eficácia vinculante, possui apenas força persuasiva, na medida em que constitui indício de uma solução racional e socialmente adequada". Consequentemente, nenhuma súmula, exceto a vinculante, tem força obrigatória. 
O Superior Tribunal de Justiça poderá editar súmulas com o objetivo de uniformizar a jurisprudência e também nas causas em que os membros desta Corte Especial ou da Seção votem por unanimidade ou por maioria absoluta em pelo menos dois julgamentos concordantes.

Em que pese o entendimento majoritário de que as súmulas do STJ tem efeito apenas persuasivo, há quem afirme, a exemplo de Marinori (2011, p.501), que os precedentes do Superior do Tribunal de Justiça são obrigatórios em relação aos tribunais de justiça e tribunais federais, somente podendo o próprio STJ revogar tais disposições.

\section{A SÚMULA 385 DO TRIBUNAL SUPERIOR DE JUSTIÇA}

A Súmula 385 do STJ foi editada em momento histórico em que o brasileiro, ciente de seus direitos enquanto consumidor, recorre com maior intensidade ao judiciário em busca de efetiva reparação em face de danos materiais, morais e estéticos ocasionados na relação de consumo. O objetivo é evitar o ingresso de ações de indenização por dano moral, fundadas na inserção indevida do nome do consumidor em cadastro de devedores inadimplentes.

\subsection{Responsabilidade Civil pela inserção indevida do nome de consumidor nos bancos de dados de devedores inadimplentes}

A legislação nacional vigente reconhece o consumidor como parte mais vulnerável na relação de consumo. Essa assertiva encontra fundamento na Carta Constitucional de 1988, na qual se encontra expresso, em diversos artigos, que a defesa do consumidor é um princípio a ser observado em toda e qualquer atividade econômica.

No mesmo sentido dispõe a Política Nacional de Relações de Consumo, em seu art. $4^{\circ}$, I, ao reconhecer a vulnerabilidade do consumidor em face do fornecedor. Por sua vez, o Código de Defesa do Consumidor (CDC), enquanto microssistema jurídico composto de normas materiais e processuais, garante instrumentos através dos quais o consumidor poderá discutir/defender seus interesses. Um deles está expresso no art. $6^{\circ}$, VII, verbis:

Art. $6^{\circ}$. São direitos básicos do consumidor:

$[\ldots]$

VIII - o acesso aos órgãos judiciários e administrativos com vistas à prevenção 
ou reparação de danos patrimoniais e morais, individuais, coletivos ou difusos, assegurada a proteção Jurídica, administrativa e técnica aos necessitados;

Igualmente, encontra previsão no CDC, também no art. $6^{\circ}$, inciso VI, o direito à reparação aos danos experimentados pelo consumidor, sendo certa a obrigação de indenizar na exata medida da extensão do dano patrimonial ou extrapatrimonial/moral sofrido.

O CDC também regula o procedimento de controle de banco de dados e cadastro de seus consumidores. Em seu art. 43, fica a clara a exigência de que todas as anotações contidas em bancos de restrição ao crédito devem corresponder à realidade, pois, se assim não o for, haverá desvirtuamento de suas finalidades, fato que traria prejuízos à sociedade como um todo e não apenas ao consumidor lesado.

Além disso, o parágrafo segundo do mesmo artigo estabelece que abertura do cadastro deverá ser comunicada ao consumidor, quando não solicitada por ele. Trata-se de um dever legal e, como tal, seu descumprimento caracteriza ilícito. É a conclusão a que chega Melo (2012, p.348) ao dispor que:

[...] há uma obrigação legal da parte do banco de dados de informar ao consumidor que irão cadastrá-lo, isso como forma de permitir-lhe verificar a exatidão ou não dos dados sobre sua pessoa.

$[\ldots$.

Esse dever de comunicação, além de expressa previsão do art. 43, é corolário dos direitos básicos e genéricos estatuídos no art. $6^{\circ}$ da lei consumerista, e a sua falta configura ato ilícito, gerando, por via de consequência, a obrigação de indenizar.

Diante, por um lado, de todos esses direitos e garantias estabelecidos pela Constituição de 1988 e pelas normas infraconstitucionais e, de outro, dos frequentes abusos praticados pelos fornecedores de produtos e serviços, a indenização por dano moral nas relações consumeristas é temafrequentemente levado ao Judiciário brasileiro.

De acordo com Theodoro Júnior (2008, p.356), os pedidos de indenização por dano moral estão mais frequentemente relacionados a lançamento de inadimplemento inexistente; a dívida em discussão judicial e a falta de comunicação prévia a respeito da inserção do nome do consumidor em cadastro de proteção ao crédito. 
Por entender o dano moral como uma grave ofensa aos direitos inerentes à personalidade, Assis (apud GRINOVER et al, 2011, p.496) é enfático ao afirmar que:

“[...] não parece haver a menor dúvida de que, comparativamente aos danos patrimoniais, os direitos inerentes à personalidade se ostentam axiologicamente mais relevantes. Merecem proteção mais acurada. É mais importante indenizar a lesão à honra, à fama, à imagem, à privacidade do que uma bicicleta e um automóvel".

Nesse contexto, a inserção indevida do nome de consumidor em cadastros inadimplentes, porque provoca constrangimentos de todas as ordens, é tida como ato ilícito, devendo, segundo doutrina e jurisprudência mais autorizada, ser exemplarmente combatida.

Grinover (2011, p.496), por exemplo, argumenta que os valores das indenizações por dano moral devem ser substanciais, a fim de que cumpram sua função pedagógica perante aquele que infringiu a norma jurídica. No entendimento desta doutrinadora (2011, p.247):

[...] os danos morais levam em conta o caráter repetitivo da prática, bem como a persistência em recusar atendimento aos reclamos legítimos do consumidor, conotação essa que, de novo lembramos, é própria ao seu caráter punitivo, já que sua finalidade não é exclusivamente ressarcitória.

Sobre este tema, o Superior Tribunal de Justiça (STJ) mantinha consolidado entendimento no sentido de que o prejuízo moral que um consumidor sofre por ter seu nome inscrito equivocadamente em cadastros de inadimplentes é provado in reipsa (pela força dos próprios fatos), razão pela qual o consumidor ficaria dispensado de provar o prejuízo efetivamente sofrido.

Nesse sentido, acórdão em Recurso Especial n ${ }^{0} 786.239$ - SP (2005/ 0166174-0), da relatoria do Ministro Sidnei Beneti:

EMENTA

RESPONSABILIDADECIVIL.ENCERRAMENTODECONTA-CORRENTE COM QUITAÇÃO DE TODOS OS DÉBITOS PENDENTES. INCLUSÃO INDEVIDA DO NOME DA CLIENTE NOS ÓRGÃOS DE PROTEÇÃO AO CRÉDITO. DANO MORAL PRESUMIDO. VALOR DA REPARAÇÃO. CRITÉRIOS PARAFIXAÇÃO. CONTROLE PELO STJ. POSSIBILIDADE. I - O banco é responsável pelos danos morais causados por deficiência na 
prestação do serviço, consistente na inclusão indevida do nome de correntista nos órgãos de proteção ao crédito, causando-lhe situação de desconforto e abalo psíquico.

II - Em casos que tais, o dano é considerado in reipsa, isto é, não se faz necessária a prova do prejuízo, que é presumido e decorre do próprio fato e da experiência comum. (grifo nosso)

III - Inexistindo critérios determinados e fixos para a quantificação do dano moral, recomendável que o arbitramento seja feito com moderação, atendendo às peculiaridades do caso concreto, o que, na espécie, não ocorreu, distanciando-se o quantum arbitrado da razoabilidade.

Recurso Especial parcialmente provido.

Também de acordo com esse raciocínio, a decisão do Agravo Regimental no Recurso Especial n ${ }^{\circ} 1.015 .111$ - RS (2007/0296279-9):

EMENTA

AGRAVO INTERNO. DANOS MORAIS. INSCRIÇÃO NOS SERVIÇOS DE PROTEÇÃO AO CRÉDITO. CDC, ART. $43, \S 2^{\circ}$. DESCUMPRIMENTO. EXISTÊNCIA DE QUATROREGISTROS. INFLUÊNCIA SOBRE O QUANTUM INDENIZATÓRIO. VALOR SIMBÓLICO.

A jurisprudência desta Corte orienta que no caso de existir mais de um registro restritivo de crédito, não resta totalmente descaracterizado o dano, mas o fato influi diretamente sobre o arbitramento, resultando em um valor simbólico. (grifo nosso)

Agravo improvido.

Não obstante, o entendimento do STJ a respeito do tema foi alterado depois de decisão em Recurso Especial no 1.002.985 - RS (2007/0260149-5), de relatoria do Ministro Ari Pargendler, que negou o direito à indenização por danos morais a consumidor que possuía registros legítimos anteriores em cadastros de proteção crédito.

EMENTA

CONSUMIDOR. INSCRIÇÃO EM CADASTRO DE INADIMPLENTES. DANO MORAL INEXISTENTE SE O DEVEDOR JÁ TEM OUTRAS ANOTAÇÕES, REGULARES, COMO MAU PAGADOR. Quem já é registrado como mau pagador não pode se sentir moralmente ofendido por mais uma inscrição do nome como inadimplente em cadastros de proteção ao crédito;dano moral, haverá se comprovado que as anotações anteriores foram realizadas sem a prévia notificação do interessado.

Recurso especial não conhecido. 
Devido à multiplicidade de recursos com fundamento em idêntica questão de direito, instaurou-se dissídio jurisprudencial no âmbito do STJ, a ser resolvido por meio da técnica de solução de recursos repetitivos, na forma do art. 543-C do Código de Processo Civil. Do julgamento de recurso representativo da controvérsia, foi editada a Súmula 385 .

\subsection{Introdução da Súmula 385 do STJ no ordenamento jurídico brasileiro}

Conforme exposto, a multiplicidade de recursos relativos a pedidos de indenização por danos morais decorrentes de inscrição do nome do devedor em cadastros de restrição ao crédito, com ausência de comunicação prévia, sobretudo nos casos onde o devedor já possua inscrições anteriores em cadastros de devedores, fez surgir no âmbito do Superior Tribunal de Justiça controvérsia jurisprudencial que gerou o julgamento do Recurso Especial 1.062.336/RS, com os efeitos do art. 543-C, do CPC.

Tal julgamento enfrentaria as seguintes questões de direito:

1) o dever de indenizar os danos morais pela falta de comunicação prévia; e

2) a repercussão da pré-existência de outros registros negativos em nome do devedor no momento da fixação da indenização.

Sob a relatoria da Ministra Nancy Andrighi, o Recurso Especial em comento foi julgado pela 2 C" Seção do STJ, com o seguinte Acórdão:

\section{EMENTA}

Direito processual civil e bancário. Recurso especial. Ação de compensação por danos morais. Inscrição em cadastro de proteção ao crédito sem prévia notificação. Dano moral reconhecido, salvo quando já existente inscrição desabonadora regularmente realizada, tal como ocorre na hipótese dos autos. I- Julgamento com efeitos do art. 543-C, § $7^{\circ}$, do CPC.

- Orientação: A ausência de prévia comunicação ao consumidor da inscrição do seu nome em cadastros de proteção ao crédito, prevista no art. $43, \S 2^{\circ}$ do $\mathrm{CDC}$, enseja o direito à compensação por danos morais, salvo quando preexista inscrição desabonadora regularmente realizada. Vencida a Min. Relatora quanto ao ponto. (grifo nosso)

II- Julgamento do recurso representativo.

- Não se conhece do recurso especial quando o entendimento firmado no acórdão recorrido se ajusta ao posicionamento do STJ quanto ao tema. Súmula n. ${ }^{\circ} 83 / \mathrm{STJ}$.

Recurso especial não conhecido. 
Em seguida, foi editada a Súmula 385, publicada em 08.06.2009, com a seguinte ementa: "Da anotação irregular em cadastro de proteção ao crédito, não cabe indenização por dano moral, quando preexistente legítima inscrição, ressalvado o direito a cancelamento".

O julgamento deste recurso representativo demonstra a mudança de entendimento do STJ a respeito do tema. Anteriormente, prevalecia o entendimento de que a existência de outras inscrições desabonadoras somente seria levada em consideração pelo julgador no momento de fixação do valor da indenização, não sendo, entretanto, afastada possibilidade de indenização, posto que ainda nesta hipótese estaria caracterizado o dano moral e, por conseguinte, o direito à indenização.

É importante ressaltar que a Relatora do Recurso foi vencida precisamente neste aspecto. Em seu voto, a Ministra evidencia a necessidade de punição da prática ilícita de inscrição indevida no cadastro de proteção ao crédito, na forma do $\S 2^{\circ}$ do art. 43 do CDC. Em suas palavras:

Não se pretende, é certo, premiar consumidores inadimplentes, mas é de suma importância o caráter pedagógico da punição ao órgão responsável pelo banco de dados que faz a negativação de forma indevida.

$\mathrm{O} C D C$ é claro em determinar que a abertura de registros não solicitados deve ser comunicada ao consumidor. O descumprimento de tal regra leva à configuração do dano moral, como aqui já destacado. Assim, permitir que os responsáveis pelo cometimento de um ato ilícito se escondam sob a alegação de que o devedor já possuía outras anotações implica cobrirlhes com o "manto da impunidade" e estimular a prática de novas ilegalidades.

Em que pese os argumentos apresentados pela relatora, prevaleceu o entendimento de que a existência de outras inscrições em nome do devedor afastava o dever de indenização por danos morais, sob o argumento de que nesta hipótese, o consumidor não experimentaria qualquer prejuízo por conta de nova inscrição.

Melo (2011, p.354), analisando o teor da Súmula 385 indica que o STJ criou algumas presunções, a saber: "a) qualquer cidadão que tenha uma segunda inscrição em banco de dados é um devedor contumaz; b) se é assim, uma segunda inscrição não aumenta o descrédito contra essa pessoa, no meio social em que ela vive; c) se é devedor contumaz, uma segunda inscrição não ofende sua honra". 
Ante o exposto, o atual entendimento do STJ é no sentido de que, mesmo em se tratando de registro indevido e não comunicado, ou seja, mesmo estando demonstrada a prática ilícita do fornecedor, o consumidor não sofre prejuízo no caso de possuir um ou vários registros legítimos anteriores em órgão de proteção ao crédito, descaracterizando, portanto, o dano moral.

\section{A (IN) CONSTITUCIONALIDADE DA SÚMULA 385 DO STJ}

Toda e qualquer norma positivada pode ser apreciada sobre o prisma de sua constitucionalidade. A Súmula 385 do STJ por conter entendimento não pacificado merece um estudo cuidadoso, especialmente em face do princípio da dignidade da pessoa humana e dos direitos e garantias fundamentais.

\subsection{O princípio da dignidade da pessoa humana como fundamento da ordem constitucional brasileira}

Em tempos de trabalho escravo, desigualdades sociais extremas, intolerância racial, entre outros, a dignidade da pessoa humana surge como tema recorrente nas legislações internas de vários países, bem como em acordos e tratados internacionais, com maior ou menor grau de destaque.

Diante da importância conferida pelos ordenamentos jurídicos contemporâneos, de um lado, e do elevado grau de abstração do termo, faz-se necessário, preliminarmente, conceituar a expressão. Para tanto, será apresentada a definição estabelecida por Sarlet (2012, p.73), para quem a dignidade da pessoa humana é:

[....] a qualidade intrínseca e distintiva reconhecida em cada ser humano que o faz merecedor do mesmo respeito e consideração por parte do Estado e da comunidade, implicando, nesse sentido, um complexo de direitos e deveres fundamentais que assegurem a pessoa tanto contra todo e qualquer ato de cunho degradante e desumano, como venham a lhe garantir as condições existenciais mínimas para uma vida saudável, além de propiciar e promover sua participação ativa e co-responsável nos destinos da própria existência e vida em comunhão com os demais seres humanos, mediante o devido respeito aos demais seres que integram a rede da vida.

No Brasil, a dignidade da pessoa humana encontra fundamento primordial na Constituição Federal de 1988, expressa em seu Título I, que aborda os 
princípios fundamentais da República Federativa do Brasil. A disposição desse fundamento logo no artigo primeiro da Carta Política parece demonstrar, desde logo, a preponderância desse valor, em face das demais disposições constitucionais.

Enquanto norma fundamental do ordenamento jurídico-constitucional pátrio, a dignidade da pessoa humana é valor informador de toda a ordem jurídica, consequentemente influenciando a interpretação das normas constitucionais e infraconstitucionais. Nas palavras de Mendes, Coelho e Branco (2007, p.27), será a partir deste e de outros princípios que serão construídas as regras de decisão por juízes e tribunais, realizando a justiça em sentido material.

Isso significa dizer que todas as demandas levadas ao conhecimento do judiciário devem ser apreciadas à luz do princípio da dignidade da pessoa humana, servindo de base para exegese das normas positivadas. Nesse sentido, Sarlet (2012, p.95) esclarece sobre a exata função deste princípio constitucional ao informar que:

[...] impõe-se seja ressaltada a função instrumental integradora e hermenêutica do princípio, na medida em que este serve de parâmetro para aplicação, interpretação e integração não apenas dos direitos fundamentais e das demais normas constitucionais, mas de todo o ordenamento jurídico.

Sendo princípio legitimador de todo ordenamento jurídico, é também fundamento normativo dos direitos e garantias fundamentais, conforme aponta Barroso (2010,p.11):

A dignidade humana, então, é um valor fundamental que se viu convertido em princípio jurídico de estatura constitucional, seja por sua positivação em norma expressa seja por sua aceitação como um mandamento jurídico extraído do sistema. Serve, assim, tanto como justificação moral quanto como fundamento normativo para os direitos fundamentais.

No mesmo sentido evidencia Sarlet (2012, p.101), estabelecendo a relação entre o princípio da dignidade da pessoa humana e os direitos fundamentais:

Com efeito, sendo correta a premissa de que os direitos fundamentais constituem - ainda que com intensidade variável - explicitações da dignidade da pessoa, por via de consequência e, ao menos em princípio (já que exceções são admissíveis, consoante já frisado), em cada direito fundamental se faz presente um conteúdo ou, pelo menos, alguma projeção da dignidade da pessoa. 
Consequentemente, estando a defesa do consumidor no rol de direitos e garantias fundamentais (Art. $5^{\circ}$, inciso XXXII, da CF), nada mais plausível que as normas constitucionais e infraconstitucionais relativas a este direito sejam interpretadas de acordo com o princípio jurídico em comento.

\subsection{A inconstitucionalidade da Súmula 385 do STJ frente ao princípio da dignidade da pessoa}

Conforme exposto, pelo princípio da dignidade da pessoa humana, não pode o homem ser observado como uma engrenagem ou como um instrumento necessário para consecução de um objetivo específico. Seu valor encontra-se consagrado na Constituição Federal de 1988, devendo ser protegido por todo o ordenamento jurídico pátrio.

Resta claro, por essa interpretação, que o Estado deve não apenas reconhecer a dignidade da pessoa humana como princípio constitucional, como também garantir os instrumentos necessários à sua proteção, conforme aponta Sarlet (2012, p.80 e 81):

[...] o nosso Constituinte de 1988 - a exemplo do que ocorreu, entre outros países, na Alemanha -, além de ter tomado uma decisão fundamental a respeito do sentido, da finalidade e da justificação do exercício do poder estatal e do próprio Estado, reconheceu categoricamente que é o Estado que existe em função da pessoa humana, e não o contrário, já que o ser humano constitui finalidade precípua, e não meio da atividade estatal.

Em caso de inércia do Estado em cumprir o compromisso firmado na Constituição Federal, surge a possibilidade de efetivação de seus direitos pela via judicial. Entretanto, a edição da Súmula 385 pelo Superior Tribunal de Justiça leva a conclusão que esta Corte ignorou por completo tal disposição constitucional, ferindo, em um só passo, vários direitos fundamentais e por via de consequência, o princípio da dignidade da pessoa humana, conforme será demonstrado nas próximas linhas.

O primeiro direito fundamental violado é o direito de ação, previsto no art. $5^{\circ}$, inciso XXXV, da CF, visto que a Súmula 385 inviabiliza a interposição de recursos que versem sobre o tema ementado, impossibilitando o reexame do caso concreto levado ao conhecimento do Poder Judiciário. Sobre este aspecto, Sacco Neto (2011, p.190) entende que: 
[...] seu enunciado [...] viola o direito de ação, previsto no art. $5^{\circ}, \mathrm{XXXV}$, porque pretende excluir, da apreciação do Poder Judiciário, lesão consistente em anotação irregular constante em desfavor do consumidor cadastrado na condição de inadimplente perante os órgãos de proteção ao crédito.

A proteção à honra, enquanto direito fundamental da personalidade, igualmente prevista no art. $5^{\circ}$, inciso $\mathrm{X}$, da $\mathrm{CF}$, também é afrontada pelo conteúdo da súmula em comento, posto que afasta a possibilidade de indenização por dano moral, por presumir que o consumidor que possua inscrição legítima anterior, não experimenta prejuízos ou dissabores em função de inscrição posterior, ainda que ilegítima.

Nesse aspecto, parece-nos mais razoável o entendimento da Ministra Nancy Andrighi a respeito da controvérsia, que entende que a existência de dois ou mais apontamentos não afasta a caracterização do dano moral, prevalecendo ainda nessa hipótese o dever de proteção ao consumidor, garantido constitucionalmente.

Por esse raciocínio, competiria ao magistrado, à luz do caso concreto, analisar se autor da ação faz jus à indenização pleiteada. As anotações anteriores de inadimplência poderiam ser consideradas para redução do pedido de indenização ou mesmo para o afastamento do pedido de indenização. Esse também é o entendimento de Antony Filho (2009, p.1) sobre a fixação da indenização:

É verdade que o princípio da razoabilidade deve ser observado quando da fixação de indenização com o fim de evitar o enriquecimento ilícito do demandante, sem, contudo deixar de punir o causador do dano, para que este não venha a proceder da mesma forma no futuro.

Além disso, a Súmula também inviabiliza qualquer possibilidade de punição àquele que praticou ato ilícito contra o consumidor. Isso implica dizer que o responsável pelo registro indevido do nome do consumidor em cadastro de proteção ao crédito não receberá qualquer tipo de reprimenda pelo ato praticado.

Nesse sentido, a súmula infringe o direito à indenização por dano material, moral e à imagem, estabelecido no art. $5^{\circ}$, inciso $\mathrm{V}, \mathrm{da} \mathrm{CF} / 88$, que encontra seu fundamento no fato de que dano injusto acarreta o dever de reparação.

Além disso, a Súmula 385 também ofende o princípio da isonomia, pois equipara o devedor que detém inúmeros apontamentos de inadimplência àquele que, em situação específica, não conseguiu honrar o pagamento de uma dívida 
ou ainda àquele que discute judicialmente o valor da dívida em questão. Não se trata de situações idênticas, conforme faz parecer a Súmula, razão pela qual o tratamento também não pode ser uniforme.

Sobre a questão da isonomia, o então Ministro do STF, Eros Grau, em Ação Direta de Inconstitucionalidade n. ${ }^{\circ} 3.305 / 2006$, alertou sobre a necessidade de o julgador observar as peculiaridades do caso concreto. De acordo com seu ensinamento:

A concreção do princípio da igualdade reclama a prévia determinação de quais sejam os iguais e quais os desiguais, até porque - e isso é repetido automaticamente, desde Platão e Aristóteles - a igualdade consiste em dar tratamento igual aos iguais e desigual aos desiguais.

\section{$[\ldots]$}

Vale dizer: o direito deve distinguir pessoas e situações distintas entre si, a fim de conferir tratamentos normativos diversos a pessoas e a situações que não sejam iguais.

Pelos motivos acima destacados, o princípio fundamental e estruturante da dignidade da pessoa humana também é violado pela Súmula 385 do STJ.

\section{CONCLUSÃO}

O ordenamento jurídico brasileiro passou adotar com maior intensidade os precedentes judiciais, sobretudo após a Reforma do Poder Judiciário. As súmulas, nesse contexto, são os exemplos mais conhecidos desses institutos, que visam conferir segurança jurídica e estabilidade às decisões judiciais.

Embora persista polêmica na doutrina a respeito da adoção de súmulas, é fato que elas têm sido editadas com certa frequência pelos tribunais, especialmente pelo Superior Tribunal de Justiça (STJ).

Foi com o intuito acima descrito que o STJ editou a Súmula 385, que inviabiliza a indenização por dano moral ao consumidor em caso de anotação irregular em cadastro de proteção ao crédito, quando preexista legítima inscrição desabonadora. Conforme analisado, a Súmula 385 do STJ ofende direitos e garantias fundamentais consagrados na Constituição Federal de 1988, a saber: a defesa do consumidor; o direito de ação; os direitos inerentes à personalidade e o princípio da isonomia.

Por via obliqua, estando estes mesmos direitos e garantias fundamentais intimamente vinculados ao princípio constitucional da dignidade da pessoa humana, a Súmula 385 do STJ também contraria este fundamento basilar do ordenamento jurídico pátrio. 
Nesse aspecto, é importante lembrar que o princípio da dignidade da pessoa, enquanto fundamento, deve ser utilizado com duas finalidades. A primeira, como critério de interpretação das normas constitucionais e infraconstitucionais, buscando sempre a aplicação que melhor concretize este princípio. No caso do CDC, está função fica ainda mais evidente, posto que o ordenamento jurídico reconhece o consumidor como a parte mais fraca da relação consumerista.

A segunda finalidade do princípio da dignidade da pessoa estaria relacionada à obrigatoriedade de fazer cessar toda e qualquer norma positivada que lesione direitos e garantias fundamentais. Assim sendo, havendo norma violadora do princípio da dignidade da pessoa humana esta deve ser excluída do ordenamento jurídico. Este é o caso da Súmula 385 do STJ, razão pela qual, em última análise, torna-se indispensável a declaração de sua inconstitucionalidade.

\section{REFERÊNCIAS}

ANTONY FILHO, Flávio Cordeiro. Conseqüências da Aplicação indiscriminada da Súmula STJ n. ${ }^{\circ}$ 385. In Revista Jurídica Consulex, Brasília, ano XIII, n. ${ }^{\circ}$ 305, $1 \mathrm{p}$.

BARROSO, Luís Roberto Barroso. A Dignidade da Pessoa Humana no Direito Constitucional Contemporâneo: Natureza Jurídica, Conteúdos Mínimos e Critérios de Aplicação. Versão provisória para debate público. Mimeografado, dezembro de 2010. Disponível em: $<$ http:// www.luisrobertobarroso.com.br/wp-content/uploads/2010/12/

Dignidade_texto-base_11dez2010.pdf $>$ Acesso em: 10.10.2012.

BRASIL. Constituição da República Federativa do. Brasília: Congresso Nacional Federal,1988.

Lei $\mathbf{n}^{\circ} \mathbf{5 . 8 6 9 / 7 3}$ - Código de processo Civil. Congresso

Nacional, Brasília, 11 de janeiro de 1973

. Lei n. ${ }^{\circ}$ 8.078/90 - Código de Defesa do Consumidor.

Congresso Nacional, Brasília, 1.990.

- Superior Tribunal de Justiça. Agravo Regimental no Recurso

Especial no 1.015.111 - RS (2007/0296279-9). Disponível em: 
http://www.stj.jus.br/webstj/processo/justica/detalhe.asp?numreg=20080032 $6041 \& p v=000000000000$. Acesso em 04.10.2012.

. Superior Tribunal de Justiça. Recurso Especial n. ${ }^{\circ} \mathbf{7 8 6 . 2 3 9}$ SP (2005/0166174-0). Disponível em: https://ww2.stj.jus.br/ revistaeletronica/ita.asp? registro $=200501661740 \& d t \_$publicacao $=13 / 05 /$ 2009. Acesso em 04.10.2012

. Superior Tribunal de Justiça. Recurso Especial $\mathbf{n}^{0} \mathbf{1 . 0 0 2 . 9 8 5}$ RS (2007/0260149-5). Disponível em: http://www.stj.jus.br/webstj/ processo/justica/detalhe.asp?numreg $=200702601495 \& \mathrm{pv}=000000000000$. Acesso em 04.10.2012.

. Superior Tribunal de Justiça. Súmula n. ${ }^{\circ}$ 387, disponível em. http:// stj.jus.br, acesso em 04.10.12.

DIDIER, Fredie Júnior; BRAGA, Paula Sarno; OLIVEIRA, Rafael. Curso de Direito Processual Civil: Teoria da Prova, Direito Probatório, Teoria do Precedente, Decisão Judicial, Coisa Julgada e Antecipação dos Efeitos da Tutela. 5Ed. Salvador: JusPodvim, 2010, v.2, 516p.

GRINOVER, Ada Pellegrini. Et al. Código de Defesa do Consumidor: Comentado pelos autores do anteprojeto. 10.ed. Rio de Janeiro: Forense, 2011, 937p.

MARINORI, Luiz Guilherme. Precedentes Obrigatórios. 2ed.São Paulo: Revista dos Tribunais, 2011, 542p.

MARINS, Lucas Belloc. A Sistemática da Teoria do Precedente Judicial e a gradual introdução de princípios do Common Law no Direito Brasileiro.Disponível em: $<\underline{\text { http://www.abdpc.org.br/abdpc/artigos/ }}$ Lucas $\% 20$ Belloc $\% 20$ Marins $\% 20 \% 20$ vers $\%$ C3\%A30\%20final.pdf $>$. Acesso em: 15.05.2012.

MELO, Nehemias Domingos. Dano moral nas relações de consumo: Doutrina e jurisprudência. 2ed: São Paulo: Saraiva, 2012. 377p. 
MENDES, Gilmar Ferreira; COELHO, Inocêncio Mártires; BRANCO, Paulo Gustavo Gonet. Curso de Direito Constitucional. São Paulo: Saraiva, 2007, 1363p.

PORTO, Sérgio Gilberto. Sobre a Common Law, Civil Law e o Precedente Judicial. Disponível em: <http://www.abdpc.org.br/abdpc/ artigos/Sergio\%20Porto-formatado.pdf.> Acesso em 31.05.2012.

RIBAS, Emanuela Catafesta. A súmula impeditiva de recursos à luz dos princípios constitucionais. Disponível em:

$<$ http://dspace.c3sl.ufpr.br/dspace/bitstream/handle/1884/17066/ dissertação\%20mestrado.pdf;jsessionid=96A1EF6D2501AE80F445A3 B41B198AEA? sequence=1>. Acesso em 03.06.2012.

SACCO NETO, Fernando. Recorribilidade diante da Súmula 385 do STJ. In: NERY JUNIOR, Nelson, WAMBIER, Tereza Arruda Alvim. Aspectos polêmicos e atuais dos recursos cíveis e assuntos afins. Ed: São Paulo: Revista dos Tribunais, 2011, v.12, 187 a 207p.

SARLET, Ingo Wolfgang. Dignidade da Pessoa Humana e Direitos Fundamentais na Constituição Federal de 1988.9 ed: Porto Alegre: Livraria do Advogado, 2012, 192p.

SCHAFER. Gilberto. Súmulas Vinculantes: Análise crítica da experiência do Supremo Tribunal Federal. Porto Alegre: Livraria do Advogado, 2012, 184p.

SOARES, Roberta Chaves. Controle de constitucionalidade das súmulas de efeitos vinculantes. In: CASTRO, João Antônio Lima. Direito Processual Constitucional e Democrático. Ed. Belo Horizonte: Puc Minas. Instituto de Educação Continuada, 2008, 95 a 103p.

THEODORO JÚNIOR, Humberto. Direitos do Consumidor: a busca de um ponto de equilíbrio entre as garantias do Código de Defesa do Consumidor e os princípios gerais do direito civil e do direto processual civil. $5^{\circ}$.ed. Rio de Janeiro: Forense, 2008, 444p.

Submetido em: 28/06/2013 Aprovado em: 08/07/2013

Como citar: POZZETTI, Valmir César; PANJOTA Aline Susana Canto. A (In) constitucionalidade da súmula 385 do Superior Tribunal de Justiça. Scientia Iuris, Londrina, v.17, n.1, p.27-48, jul.2013. DOI: 10.5433/2178-8189.2013v17n1p27. 